Biografistyka Pedagogiczna

Rok 2 (2017) nr 1

ISSN 2543-6112; e-ISSN 2543-7399

DOI: $10.36578 /$ BP.2017.02.07

Edyta Żebrowska*

\title{
Tadeusz Łopuszański - twórca i dyrektor Szkoły Rydzyńskiej
}

\section{Tadeusz Łopuszański - Creator and Director of the Rydzyna School}

\begin{abstract}
Tadeusz Łopuszański (1874-1955) created the Rydzyna School to educate future intellectuals capable of creative, hard work for the benefit of the emerging state. He believed that future elites were responsible for the reconstruction of Poland and its success or failure. According to him, proper education could transform the character of a man and encourage them to devote their life to saving Poland. His concept of education was based on several solid foundations - the pillars of Rydzyna: developing individual interests, social work, manual work, extended physical activity and fighting against lies. Although the Rydzyna School (1928-1939) did not exist long, its graduates were active on many levels in the newly formed state after the war. The education of young people, who were able to find their place in the difficult post-war reality, was possible thanks to the proper organisation of school life, and this was mainly to the credit of its founder, Tadeusz Łopuszański.
\end{abstract}

Keywords: Tadeusz Łopuszański, Rydzyna School, experimental school

* Edyta Żebrowska - mgr, doktorantka w Akademii Pedagogiki Specjalnej im. Marii Grzegorzewskiej w Warszawie, edytazebrowska.ez@gmail.com. 
Tadeusz Łopuszański znany jest w literaturze naukowej jako założyciel i dyrektor Szkoły Rydzyńskiej'. Szkołą tą interesują się badacze nieprzerwanie niemalże od momentu jej powstania ${ }^{2}$. Wincenty Okoń zaliczył ją do jednej z dzie-

1 Szkoła Rydzyńska założona i prowadzona przez Tadeusza Łopuszańskiego, ministra, a później wiceministra wyznań religijnych i oświecenia publicznego (WRioP) w latach 1928-1939; istniała zaledwie 11 lat, maturę zdało w niej 114 uczniów, a zetknęło się z nią około 280 uczniów, którzy w wyniku wybuchu wojny oraz innych okoliczności nie mieli możliwości zdawania w niej matury. Była to męska, internatowa szkoła, która za cel najważniejszy stawiała nie kształcenie intelektualne, ale moralne swoich wychowanków. Szkołę mieli opuszczać ludzie o wyraźnie zarysowanych cechach: wysokiej etyce osobistej, a szczególnie uczciwości, uznający prawdę i czystość życia osobistego za wartości podstawowe, a także odznaczający się wielką prostotą, zdrowiem i hartem ducha, ponadto wrażliwi na ludzką niedolę i gotowi do pomocy i współdziałania, jednakże niedążący do karierowiczostwa, bez cech egoistycznych. Absolwent Szkoły Rydzyńskiej miał być patriotą o głębokim poczuciu osobistej odpowiedzialności za losy narodu, silnie odczuwający potrzebę pracy społecznej, a także posiadający zdolności organizacyjne, cywilną odwagę i gotowość wzięcia odpowiedzialności za podejmowane decyzje. Ponadto były rydzyniak powinien posiadać z jednej strony ogólną wiedzę na temat najważniejszych zjawisk i zagadnień społecznych, a z drugiejgruntowną i głęboką w konkretnej dziedzinie, aby mógł stale ją poszerzać w ramach indywidualnej pracy twórczej. Miał to być nowy typ inteligenta polskiego, który byłby zdolny do przebudowy odradzającego się państwa (A. H. Piekara, Poglądy społeczne i pedagogiczne Tadeusza Łopuszańskiego, w: tenże, Nayiasnieyszemu y naypotęznieyszemu Panu czyli O nauki horyzontach dalekich, Warszawa 1986).

2 F.W. Araszkiewicz, Życie i działalność oświatowo-pedagogiczna Tadeusza Jana Łopuszańskiego, „Przegląd Historyczno-Oświatowy”, 1973, nr 1-4, s. 498-511; tenże, Tadeusza Jana Łopuszańskiego koncepcja szkoły średniej ogólnokształcacej, Rydzyna 1987; K. Brończyk, Recenzja: T. Łopuszański „Rydzyna”. Pierwsze ośmiolecie gimnazjum im. Sułkowskich w Rydzynie, „Muzeum. Czasopismo Pedagogiczne Poświęcone Sprawom Wychowania, Nauczania i Organizacji Szkolnictwa", 1938, z. 3, s. 153-16o; V. Julkowska, Niezwykła szkoła $w$ niezwykłym miejscu. Rydzyński eksperyment wychowawczo-dydaktyczny w latach 1928-1939, w: Między historią a edukacją historyczna. Studia i szkice dedykowane Profesor Marii Kujawskiej, red. V. Julkowska, Poznań 2003, s. 66-79; D. Koźmian, Tadeusz Łopuszański i jego koncepcja Gimnazjum w Rydzynie, w: Szkolnictwo niepubliczne w Polsce i w Europie w XX wieku, red. T. Jałmużna, W. Leżańska, Łódź 2002, s. 153-166; B. Nawroczyński, Tadeusz Łopuszański (1974-1955), „Ruch Pedagogiczny”, 1969, nr 1, s. 75-83; T. W. Nowacki, Gimnazjum im. Sutkowskich w Rydzynie jako szkoła doświadczalna, „Rozprawy z Dziejów Oświaty”, 35 (1992) s. 139-179; W. Okoń, Rydzyna - elitarne gimnazjum Tadeusza Łopuszańskiego, w: tenże, 10 szkół alternatywnych, Warszawa 1997, s. 162-182; A. Piwoń, Organizacja i działalność Gimnazjum i Liceum im. Sułkowskich w Rydzynie, „Rocznik Leszczyński”, 2 (1978) s. 93-122; U. Uniewska, Gimnazjum i Liceum im. Sułkowskich w Rydzynie 1928-1939, „Amicus. Niezależna Szkoła w Polsce”, 3 (2000) nr 1 (21), s. 23-30. 
sięciu alternatywnych szkół, w której udało się osiągnąć „względną doskonałość w pracy wychowawczej i gdzie ukształtowano model szkoły nowoczesnej, spontanicznie upowszechniany, bez zarządzeń i nakazów ze strony władz"3.

Łopuszański uważał, że trudna sytuacji Polski:

[...] straszliwe braki, nędze i choroby życia polskiego i wiszące nad Polską groźne niebezpieczeństwa domagają się wielkim głosem, aby ta warstwa, w której rękach spoczywać będzie kierownictwo różnych dziedzin naszego życia, a więc polska warstwa inteligentna, potrafiła istotnie sprostać swym zadaniom organizatorskim, kierowniczym i twórczym, by potrafiła przeorać i przekształcić głęboko polską rzeczywistość i dostosować ja do wymagań niezwykle trudnej epoki i trudniejszego jeszcze położenia Narodu i Państwa, by potrafiła wlać w nie potrzebne im siły i odwrócić grożące im niebezpieczeństwa ${ }^{4}$.

Widział w inteligencji możliwość przebudowy Polski, ale pod pewnymi warunkami. Można tego dokonać, jeśli warstwa ta zmieni sposób życia, bo do tej pory „lubiła zamykać się przed rzeczywistością, odosabniać się w mało realnym światku swych inteligenckich nawyków i upodobań, usypiać się frazesami o bogactwach naszej ziemi, wielkości naszego Narodu, mocarstwowości naszego Państwa"5. Tymczasem Polsce, zdaniem Łopuszańskiego, potrzeba ludzi czynu, którzy byliby zdolni:

[...] przebudować od podstaw i to w szczególnie trudnych warunkach słabości finansowej, nędzy i ciemnoty szerokich mas, wśród zamętu gospodarczego i walk społecznych wstrząsających światem otoczeni potężnymi wrogami, zagrożeni wojną, osłabieni wewnętrznie agitacją bolszewicką i odśrodkowymi dążeniami mniejszości narodowych. Od dobrego i możliwie rychłego dokonania przebudowy podstawowych dziedzin naszego życia zależy utrzymanie się Państwa i byt Narodu ${ }^{6}$.

Aby jednak tego dokonać, należy przekształcić psychikę warstwy inteligentnej, a głównym narzędziem tej przebudowy, jak twierdził, musi stać się szkoła średnia, bo

3 W. Okoń, Rydzyna - elitarne gimnazjum Tadeusza Łopuszańskiego, s. 8.

4 T. Łopuszański, Rydzyna. Gimnazjum im. Sutkowskich (1928-1936), Rydzyna 1937, s. 8.

5 Tamże.

6 Tamże, s. 220. 
[...] przez nią przechodzi prawie cała warstwa inteligentna, a przede wszystkim dlatego, że objęty nią okres dojrzewania to jedyny okres życia, w ciągu którego oddziaływania wychowawcze przyjmują się łatwo i ryją się w psychice głęboko, w ciągu którego więc zadanie przekształcenia psychiki - nie jednostki, lecz ogółu - może być podjęte z widokami powodzenia ${ }^{7}$.

Polska potrzebuje ludzi, którzy mogliby ją przebudować i wydźwignąć z trudnego położenia, zacofania. Jest to możliwe, jeśli wykształci i wychowa się nowe pokolenie, które weźmie na siebie odpowiedzialność i rozpocznie trudną pracę na wielu płaszczyznach życia. Tacy ludzie - przyszli inteligenci powinni posiadać odpowiednie cechy.

Aby jednak takich ludzi ukształtować, potrzebne jest odpowiednie środowisko. Taką kuźnią charakterów, która mogłaby stworzyć nowy typ inteligenta polskiego, stała się Szkoła Rydzyńska. To swoiste laboratorium przygotowywało ludzi do trudnego, ofiarnego życia.

Zasadne wydaje się szczegółowe przedstawienie sylwetki Łopuszańskiego z uwzględnieniem wszystkich etapów życia, aby wydobyć te elementy, które znacząco wpłynęły na stworzenie Szkoły Rydzyńskiej. Można powiedzieć, że Szkoła Rydzyńska to efekt pracy przez całe życie, do stworzenia której wykorzystał doświadczenie zbierane najpierw jako nauczyciel, potem inspektor szkolny, następnie wizytator, wreszcie minister i wiceminister oświaty w Polsce. „Aby dobrze zrozumieć znaczenie Łopuszańskiego jako dyrektora Rydzyny w kształtowaniu życia i charakteru tej szkoły niezbędne jest ukazanie jego przygotowania do podjęcia dzieła, stanowiącego główny owoc pracowitego życia” ${ }^{8}$, bo „każdy podjęty przez niego wysiłek twórczy, wartości, którymi kierował się w życiu i w pracy, konsekwencja, z jaką doprowadzał do celu powierzone mu zadania, a nawet chwilowe niepowodzenia przygotowywały go do najważniejszej próby, jaką było stworzenie od podstaw szkoły na miarę przyszłych pokoleń"

Tadeusz Łopuszański urodził się 15 stycznia 1874 r. we Lwowie. Był synem Edwarda i Walerii z Kotiersów. Sytuacja finansowa rodziny pozwoliła mu z trudem ukończyć w 1891 r. Gimnazjum im. Św. Anny w Krakowie, a później studia wyższe na Wydziale Filozoficznym Uniwersytetu Jagiellońskiego, na którym

7 Tamże, s. 225.

8 T.W. Nowacki, Gimnazjum im. Sułkowskich w Rydzynie jako szkoła doświadczalna, s. 141.

9 V. Julkowska, Niezwykła szkoła w niezwyktym miejscu, s. 69. 
studiował matematykę i fizykę. Jego zainteresowania i zdolności w dziedzinie nauk ścisłych otwierały przed nim drogę pracy naukowej, której nie podjął świadomie, wybierając ścieżkę kariery pedagogicznej.

„Pierwsze lata samodzielnej pracy nauczycielskiej obudzily w nim pasję dydaktyczną tak wielką, że pomimo wcześniejszych planów pracy naukowej, swoją przyszłość związał ze szkołą”10. Uważał bowiem, że „zawód nauczyciela w szkole średniej jest najszczytniejszy i najbardziej Polsce potrzebny"11.

Po ukończeniu studiów wyższych podjął pracę jako nauczyciel w macierzystej szkole - Gimnazjum św. Anny w Krakowie, następnie w latach 18961899 nauczał w I Krakowskiej Szkole Realnej, a po zdaniu w 1899 r. egzaminu nauczycielskiego objął stanowisko profesora gimnazjum w Rzeszowie, w którym rozwijał swój talent dydaktyczny. Potrafił zauważyć i rozbudzić w uczniach zamiłowanie do nauk ścisłych, tak że wielu z jego podopiecznych obierało drogę naukową. Jeden z jego uczniów, któremu poświęcił bezinteresownie swój prywatny czas, dając lekcje matematyki, został kilkanaście lat później profesorem uniwersytetu. „Uczył ofiarnie, kochał młodzież, potrafił wśród niej dostrzec przyszłe talenty, przyszłych uczonych"12. Józef Świeboda w swojej książce poświęconej gimnazjum i liceum w Rzeszowie pisał, że Łopuszański był „najbardziej dynamicznym nauczycielem [...] popierającym pracę samokształceniową młodzieży, głoszącym programy zreformowania szkolnictwa [...]"13.

Udało się mu również w tym czasie przetłumaczyć i wydać podręcznik geometrii analitycznej Friedricha Heinricha Schura, który - również współcześnie - uznawany jest przez matematyków uniwersyteckich i podawany jako przykład „jasności i ścisłości wykładu"14.

W latach 1903-1909 pracował jako nauczyciel w II Krakowskiej Szkole Realnej. W tym okresie odbył podróże zagraniczne do Niemiec, Francji i Anglii w celu poznania tamtejszego szkolnictwa. Obserwacje szkół dały mu wiedzę na temat współczesnych metod pracy i zapewne stały się inspiracją do wygłoszonego w 1905 r. referatu: „Nasza szkoła średnia, krytyka jej podstaw i konieczność reformy", będącego wynikiem prac Komisji Towarzystwa Szkół

10 Tamże.

11 R. Lubańska, Tadeusz Łopuszański 1974-1955, „Kultura i Edukacja”, 2004, nr 2, s. 118

12 Tamże, s. 118.

13 J. Świeboda, Collegium Ressoviense w życiu Polaków 1658-1983, Rzeszów 1983, s. 53.

14 R. Lubańska, Tadeusz Łopuszański 1974-1955, s. 118. 
Wyższych, w skład której wchodzili krakowscy pedagodzy. W dokumencie tym pilnie wskazywano potrzebę opracowania zasad, według których szkoła miałaby funkcjonować oraz wypracowania drogą eksperymentalną modelu szkoły przyszłości.

W eksperymentalnych poszukiwaniach dostrzeżono drogę do najlepszych rozwiązań koncepcyjnych szkoły polskiej, pozwalają bowiem przystosować formy i treści wychowania do właściwości i potrzeb narodu, uświadomić główne cele wychowawcze. Stanowisko takie prezentowało koło krakowskie w 1905 r., a gorącym jego rzecznikiem był sekretarz koła Tadeusz Łopuszański, późniejszy minister WRioP w Polsce ${ }^{15}$.

Łopuszański był aktywnym działaczem w Towarzystwie Tatrzańskim, w którym w latach 1906-1907 pełnił funkcję przewodniczącego sekcji turystycznej. W 1905 r. udało mu się wraz z Janem Chmielowskim dokonać pierwszego wejścia turystycznego na Żabi Szczyt Wyżni w Tatrach.

W 1909 r. po powrocie z Anglii został wybrany do Zarządu Głównego Towarzystwa Szkoły Ludowej, a także został inspektorem szkolnym okręgowym w Krakowie, co wiązało się z nadzorem szkół, a tym samym organizacją nowych placówek, zwłaszcza na Śląsku Cieszyńskim.

Podczas II Polskiego Kongresu Pedagogicznego we Lwowie w 1909 r. przedstawił przygotowany przez siebie projekt reformy szkolnictwa średniego.

Zdaniem Łopuszańskiego należało konsekwentnie dążyć do zmian programowych na korzyść przedmiotów matematyczno-przyrodniczych oraz zmian organizacyjnych, zastępując klasyczne gimnazjum szkołą realną, tak aby zainteresowanie młodzieży skierować ku studiom technicznym i działalności ekonomicznej. Mimo uchwalenia przez Sejm galicyjski odpowiedniej ustawy, projekt organizacyjny i program średniej szkoły realnej nie doczekały się realizacji, ponieważ zabrakło wówczas szerszego zainteresowania społecznego tym typem szkoły ${ }^{16}$.

W latach 1912-1914 zajął się prowadzeniem eksperymentalnej szkoły średniej w podkrakowskim Prokocimiu.

15 J. Chodakowska, Towarzystwo Nauczycieli Szkół Wyższych i jego udział w reformie szkót średnich w Polsce międzywojennej, „Rozprawy z Dziejów Oświaty”, 29 (1986) s. 70. 16 V. Julkowska, Niezwykła szkoła w niezwykłym miejscu, s. 7 O. 
Szkoła ta, będąc oddziałem założonego na terenie zaboru rosyjskiego przez Jana Gralewskiego, Witolda Czartoryskiego i Kazimierza Lutosławskiego Polskiego Ogniska Wychowawczego Wiejskiego, nawiązywała do wzorów angielskich, z którymi Łopuszański miał okazję zapoznać się podczas swojego pobytu w Abbotsholme, działającej tam szkole średniej typu wiejskiego ${ }^{17}$.

We wrześniu 1917 r. został powołany na stanowisko naczelnego inspektora szkolnictwa elementarnego w Departamencie Wyznań Religijnych i Oświecenia Publicznego.

W grudniu 1917 r. na posiedzeniu Towarzystwa Nauczycieli Szkół Wyższych w Krakowie przedstawił projekt dotyczący szkolnictwa elementarnego, który dotyczył zastosowania dwukrotnej selekcji, tzn. uczniowie mniej zdolni po trzech latach nauki kierowani byliby do niższej szkoły ludowej, a zdolniejsi do wyższej szkoły ludowej, a z tej znów przechodziliby „mocniejsi” do sześcioklasowej szkoły ogólnokształcącej. Sprzeciwił się takiemu rozwiązaniu Marian Falski, wskazując na „elitarność koncepcji” Łopuszańskiego ${ }^{18}$.

Łopuszański przez wiele lat pracy w ministerstwie był atakowany zarówno przez prawicę, jak i lewicę:

[...] pierwszej nie podobała się elitarność koncepcji Łopuszańskiego i uprzywilejowanie - ich zdaniem - szkoły średniej, opowiadając się za doktrynalnym egalitaryzmem bez względu na realnie istniejące warunki. Drugim nie podobał się zbytni radykalizm i egalitaryzm jego koncepcji. Gdy pierwsi nie przywiązywali większej wagi do jakości nauczania, drudzy podejrzewali w każdej śmielszej reformie Łopuszańskiego socjalistyczne ciągoty ${ }^{19}$.

W 1918 r. w Piotrkowie Łopuszański wygłosił referat na temat systemu selekcyjnego „zakładający przeprowadzenie w ramach siedmioletniej szkoły powszechnej dwukrotnej selekcji, w celu wyławiania najzdolniejszych uczniów i kierowania ich do sześcioletniej szkoły średniej" ${ }^{20}$. Natomiast podczas Sejmu Nauczycielskiego

17 Tamże, s. 71.

18 T. W. Nowacki, Gimnazjum im. Sułkowskich w Rydzynie jako szkoła doświadczalna, S. 139-179.

19 Z. T. Wierzbicki, Wprowadzenie, w: T. Łopuszański, Tezy. Od pedagogiki narodowej do pedagogiki europejskiej, red. Z. T. Wierzbicki, Warszawa-Rydzyna 2000, s. 10.

20 S. Mauersberg, Sejm Nauczycielski (14-17 kwietnia 1919), „Rozprawy z Dziejów Oświaty", 23 (1980) s. 140. 
[...] wystąpił przeciw przeładowaniu programu szkoły średniej, powodującemu powierzchowne nauczanie, werbalizm i przeciążenie młodzieży pamięciowym materiałem. Domagał się więc pomniejszenia liczby przedmiotów, skrócenia programu, uczenia mniej, ale za to gruntowniej, metodami rozwijającymi samodzielność ucznia. Proponował utworzyć w szkołach średnich różne podstawy dydaktyczne (czy wychowawcze), polegające na wyposażeniu różnych grup przedmiotów w większą liczbę godzin lekcyjnych. Stałoby się to podstawą stworzenia czterech typów gimnazjum: matematyczno-fizycznego, humanistycznego bez łaciny i bez greki, humanistycznego $\mathrm{z}$ łaciną i humanistycznego $\mathrm{z}$ łaciną i greką ${ }^{21}$.

Łopuszański postawił tezę, a Zjazd ją zaakceptował, że „celem szkoły średniej jest rozwijanie fizycznych i duchowych sił młodzieży"22.

W 1921 r. był „faktycznym twórcą pierwszego stowarzyszenia naukowego polskich pedagogów"23. Z jego inicjatywy powstała Komisja Pedagogiczna, która miała ożywić pracę na gruncie nauk pedagogicznych, bo, jak twierdził:

[...] w Polsce prawie nie istnieje nie tylko pedagogiczna literatura naukowa, ale i podręcznikowa. Komisja będzie ciałem, dysponującym swobodą w doborze swoich członków, będzie też niezależna od Ministerstwa, choć będzie utrzymywać z nim kontakty ${ }^{24}$.

Komisja Pedagogiczna rozpoczęła prace na wielu płaszczyznach. Głównym zadaniem miało być, według jej twórcy, organizowanie badań zespołowych oraz konferencji naukowych, ale na skutek trudności finansowych, a także niedostatecznego wykształcenia pracowników naukowych działania te były poważnie utrudnione ${ }^{25}$. W 1922 r. utworzono oddziały Komisji specjalizujące się w wybranych dziedzinach pedagogiki. Łopuszański był z wykształcenia fizykiem i szczególnie bliskie były mu nauki ścisłe, w związku z tym w 1926 r. stanął na czele

21 Tamże, s. 150.

22 Tamże.

23 J. Miąso, Komisja Pedagogiczna Ministerstwa Wyznań Religijnych i Oświecenia Publicznego (1921-1928) i jej rola w rozwoju nauk pedagogicznych, „Rozprawy z Dziejów Oświaty", 42 (2003) s. 135.

24 Tamże, s. 138.

25 Tamże, s. 148. 
Oddziału Metodyki Fizyki i Chemii z siedzibą w Warszawie, która zajęła się wydawaniem rocznika „Fizyka i Chemia w Szkole”.

Wcześniej, bo w 1923 r., najprawdopodobniej Łopuszański zainteresował się sprawą dóbr należących do ordynacji rydzyńskiej ${ }^{26}$, które na skutek postanowień traktatu wersalskiego znalazły się w obrębie wskrzeszonej Rzeczpospolitej.

Zamek sam wraz z oficynami miał stanowić siedzibę gimnazjum państwowego, projektowanego przez Ministerstwo W. R. i O. P. jako wzorowy instytut wychowawczy. W tym celu Dyrekcja Lasów Państwowych przekazała z dniem 1 lipca 1923 zamek wraz z otoczeniem o obszarze 37 hektarów w zarząd Kuratorium Poznańskiego Okręgu Szkolnego ${ }^{27}$.

Zamek wymagał generalnego remontu. W związku z tym z inicjatywy ministerstwa (zapewne Łopuszańskiego) został utworzony komitet budowlany, który miał za zadanie zaadaptować zamek oraz oficyny na cele mającej tam powstać szkoły. Prace remontowe trwały od 23 maja 1924 r. aż do końca $1925 \mathrm{r}$. Równolegle Ministerstwo WRioP rozpoczęło starania o „rewindykację dóbr ordynackich od Skarbu Państwa dla Fundacji Sułkowskich"28. Dnia 7 stycznia 1924 r. „Ministerstwo oświaty, jako niewątpliwy następca Komisji Edukacyjnej, powołało tymczasowe Kuratorium Fundacji Sułkowskich"29, a 19 maja 1926 r. minister WRiop nadał fundacji nowy statut, który „pieczę i zarząd nad majątkiem fundacyjnym powierzał kuratorium, złożonemu z pięciu osób, mianowanych przez Ministra spośród wybitnych obywateli Państwa"30. Celem

26 W 1783 r. książę August Sułkowski z Rydzyny ustanowił na swych dobrach (ok. 10000 ha) ordynację rodową i jednocześnie tworząc zapis testamentowy, przeznaczył, w momencie wygaśnięcia jego rodu, wszystkie dobra na rzecz Komisji Edukacji Narodowej na kształcenie niezamożnej, a zdolnej młodzieży mającej dobre zadatki moralne. Śmierć ostatniego z rodu Sułkowskich przypadła na 1909 r., więc rząd pruski przekazał dobra rydzyńskie Pruskiemu Kolegium Szkolnemu jako „spadkobiercy” Komisji Edukacji Narodowej, a potem Pruskiej Komisji Kolonizacyjnej. Po odzyskaniu przez Polskę niepodległości rząd, uznając ważność zapisu testamentowego Augusta Sułkowskiego, zlecił Ministerstwu wRioP jego realizację.

27 L. Preibisz, Zamek i klucz rydzyński, Rydzyna 1938, s. 142.

28 Tamże, s. 143.

29 Tamże, s. 144.

30 Tamże. 
statutowym fundacji miało być „utrzymywanie szkół o typie powyżej szkoły powszechnej, a poniżej szkoły akademickiej oraz internatów przeznaczonych dla niezamożnej, a wyjątkowo zdolnej i obdarzonej zadatkami charakteru młodzieży polskiej" ${ }^{\prime 3}$.

W wyniku wydarzeń politycznych w 1926 r. sanacja, która przejęła władzę w kraju, usunęła ze stanowiska wiceministra oświaty Tadeusza Łopuszańskiego. „Lecz Łopuszańskiemu nie zależało na karierze osobistej, zależało mu najgoręcej na realizacji upragnionej idei, by naród nasz potrafił tak wychować swoją młodzież, aby ta chciała i potrafiła dźwignąć go na wyższy poziom i zapewnić mu lepszą przyszłość" ${ }^{\prime 2}$. Dlatego też dopiero te wydarzenia otworzyły przed nim „wbrew logice wydarzeń, hołubioną w duszy szansę przeprowadzenia na dużą skalę eksperymentu pedagogicznego w zakresie szkoły średniej" ${ }^{\prime 3}$. Zatem zgodził się na objęcie kierownictwa w Szkole Rydzyńskiej zaproponowane mu przez Kuratorium Fundacji Sułkowskich. Było to z kolei możliwe dzięki przywróceniu mocy prawnej zapisowi testamentowemu ks. Augusta Sułkowskiego.

Araszkiewicz wyróżnia trzy etapy kształtowania się koncepcji pedagogicznej Łopuszańskiego: pierwszy od 1906 r. to okres zaboru austriackiego, drugi zaczął się w 1919 r., gdy został ministrem wRioP i ostatni, trzeci okres przypadł na lata 1928-1930, gdy mógł realizować swoje koncepcje w Szkole Rydzyńskiej34.

Cel postawił sobie tak wielki, jak w przeszłości tylko najwięksi: tacy jak Andrzej Frycz Modrzewski, Stanisław Konarski, Stanisław Szczepanowski. Chciał przez wychowanie wykorzenić wady naszego społeczeństwa. Chciał przekształcić duszę narodu, aby go uzbroić w siły moralne potrzebne do zwycięskiego wyjścia z grożących mu strasznych niebezpieczeństw, które przewidywał. [...] Chciał wydźwigną̨ć naród przez przerodzenie duchowe przyszłych przywódców ${ }^{35}$.

31 Tamże.

32 A. H. Piekara, Poglądy społeczne i pedagogiczne Tadeusza Łopuszańskiego, s. 66.

33 Z. T. Wierzbicki, Wprowadzenie, s. 10.

34 F.W. Araszkiewicz, Tadeusza Jana Łopuszańskiego koncepcja szkoły średniej ogólnoksztatcącej.

35 Z. T. Wierzbicki, Wprowadzenie, s. 8. 
Na koncepcję pedagogiczną Łopuszańskiego, zdaniem Araszkiewicza, składa się polski pozytywizm, poglądy pedagogiczne i idee Stanisława Szczepanowskiego, instrumentalizm Johna Deweya oraz parę innych kierunków tzw. nowego wychowania, a zwłaszcza angielskiego, związanego z osobą Cecila Reddiego ${ }^{36}$. Niewątpliwie istotny wpływ wywarł na Łopuszańskiego Wincenty Lutosławski, twórca Eleusis, stowarzyszenia, do którego najprawdopodobniej należał.

W 1928 r. rozpoczęła się jego najważniejsza droga, która miała prowadzić do wychowania młodego pokolenia na ludzi chcących i potrafiących działać dla Polski. Bo

[...] [w]ielkie zamiłowania pedagogiczne łączyły się u Tadeusza Łopuszańskiego z głęboką wiarą popartą wieloletnim doświadczeniem i przemyśleniami,że zarówno odrodzenie społeczeństwa polskiego, jak i całej ludzkości może dokonać się jedynie na drodze odpowiedniego wychowania, nieograniczającego się tylko do młodzieży, lecz obejmującego również dorosłych ${ }^{37}$.

Analizując wszystkie działania Łopuszańskiego przed założeniem Szkoły Rydzyńskiej, można przypuszczać, że miał precyzyjnie ułożony plan, a to, co robił, zbliżało go do określonego celu - założenia eksperymentalnej placówki. Krótki okres działalności Szkoły Rydzyńskiej nie przeszkodził w tym, aby wykształcić młodych ludzi, którzy działali po wojnie na wielu płaszczyznach tworzącego się państwa. Wykształcenie takich młodych ludzi, którzy potrafili w trudnej sytuacji powojennej odnaleźć swoje miejsce, było możliwe przede wszystkim dzięki odpowiedniej organizacji życia szkolnego, a to przecież głównie zasługa jej założyciela. Z całą pewnością można Szkołę Rydzyńską stawiać za wzór dla współcześnie zakładanych placówek, bo, jak twierdzi Okoń, udało się w niej osiągnąć względną, doskonałość w pracy wychowawczej ${ }^{38}$.Zatem należy zakończyć ten krótki życiorys zdaniem Julkowskiej: „Łopuszański stworzył w Wielkopolsce model szkoły średniej ogólnokształcącej, o którym dziś możemy powiedzieć ponad wszelką wątpliwość, że wyprzedzał znacznie swoje czasy"39.

36 F. W. Araszkiewicz, Tadeusza Jana Łopuszańskiego koncepcja szkoły średniej ogólnokształcacej.

37 R. Lubańska, Tadeusz Eopuszański 1974-1955, s. 117.

38 W. Okoń, Rydzyna - elitarne gimnazjum Tadeusza Eopuszańskiego, s. 8.

39 V. Julkowska, Niezwykła szkoła w niezwykłym miejscu, s. 69. 
Streszczenie: Tadeusz Łopuszański (1874-1955) stworzył Szkołę Rydzyńską, która miała za zadanie kształcić przyszłych inteligentów zdolnych do twórczej, wytężonej pracy na rzecz tworzącego się państwa. Uważał, że w rękach przyszłych elit leży przebudowa Polski i jednocześnie jej sukces lub klęska. Wierzył, że poprzez odpowiednie wychowanie można przekształcić charakter człowieka, „przerobić” go, aby ów człowiek był zdolny poświęcić swoje życie dla ratowania Polski. Swoją koncepcję wychowania oparł na kilku solidnych podstawach - filarach rydzyńskich: rozwijaniu indywidualnych zainteresowań, pracy społecznej, pracach ręcznych, rozbudowanej aktywności fizycznej, walce z kłamstwem, rozwijaniu indywidualnych zainteresowań. Krótki okres działalności Szkoły Rydzyńskiej (1928-1939) nie przeszkodził w tym, by wykształcić młodych ludzi, którzy działali po wojnie na wielu płaszczyznach tworzącego się państwa. Wykształcenie takich młodych ludzi, którzy potrafili w trudnej sytuacji powojennej odnaleźć swoje miejsce, było możliwe przede wszystkim dzięki odpowiedniej organizacji życia szkolnego, a to przecież głównie zasługa jej założyciela - Tadeusza Łopuszańskiego.

Słowa kluczowe: Tadeusz Łopuszański, Szkoła Rydzyńska, szkoła eksperymentalna

\section{Bibliografia}

Araszkiewicz F. W., Życie i działalność oświatowo-pedagogiczna Tadeusza Jana Łopuszańskiego, „Przegląd Historyczno-Oświatowy”, 1973, nr 1-4, s. 498-511.

Araszkiewicz F. W., Tadeusza Jana Łopuszańskiego koncepcja szkoły średniej ogólnokształcącej, Rydzyna 1987.

Brończyk K., Recenzja: T. Łopuszański „Rydzyna”. Pierwsze ośmiolecie gimnazjum im. Sułkowskich w Rydzynie, „Muzeum. Czasopismo Pedagogiczne Poświęcone Sprawom Wychowania, Nauczania i Organizacji Szkolnictwa", 1938, z. 3, s. 153-160.

Chodakowska J., Towarzystwo Nauczycieli Szkół Wyższych i jego udział w reformie szkół średnich w Polsce międzywojennej, „Rozprawy z Dziejów Oświaty”, 29 (1986) s. 69-106.

Julkowska V., Niezwykła szkoła w niezwykłym miejscu. Rydzyński eksperyment wychowawczo-dydaktyczny w latach 1928-1939, w: Między historiq a edukacją historyczna. Studia i szkice dedykowane Profesor Marii Kujawskiej, red. V. Julkowska, Poznań 2003, s. 66-79.

Koźmian D., Tadeusz Łopuszański i jego koncepcja Gimnazjum w Rydzynie, w: Szkolnictwo niepubliczne $w$ Polsce i $w$ Europie $w$ XX wieku, red. T. Jałmużna, W. Leżańska, Łódź 2002, s. 153-166.

Łopuszański T., Rydzyna. Gimnazjum im. Sułkowskich (1928-1936), Rydzyna 1937.

Łopuszański, T., Szkoła doświadczalna. Trzechlecie 1936-1939 Gimnazjum i Liceum im. Sułkowskich w Rydzynie, Rydzyna 1985. 
Lubańska R., Tadeusz Łopuszański 1974-1955, „Kultura i Edukacja”, 2004, nr 2, s. 117-124. Mauersberg S., Sejm Nauczycielski (14-17 kwietnia 1919), „Rozprawy z Dziejów Oświaty”, 23 (1980) s. 139-156.

Miąso J., Komisja Pedagogiczna Ministerstwa Wyznań Religijnych i Oświecenia Publicznego (1921-1928) i jej rola $w$ rozwoju nauk pedagogicznych, „Rozprawy z Dziejów Oświaty", 42 (2003) s. 135-159.

Nasza szkoła średnia, krytyka jej podstaw i konieczność reformy, Kraków 1906.

Nawroczyński B., Tadeusz Łopuszański (1974-1955), „Ruch Pedagogiczny”, 1969, nr 1, s. 75-83.

Nowacki T. W., Gimnazjum im. Sułkowskich w Rydzynie jako szkoła doświadczalna, „Rozprawy z Dziejów Oświaty”, 35 (1992) s. 139-179.

Okoń W., Rydzyna - elitarne gimnazjum Tadeusza Łopuszańskiego, w: tenże, 10 szkół alternatywnych, Warszawa 1997, s. 162-182.

Piekara A. H., Poglądy społeczne i pedagogiczne Tadeusza Łopuszańskiego, w: Nayiasnieyszemu y naypotęznieyszemu Panu czyli O nauki horyzontach dalekich, Warszawa 1976.

Piwoń A., Organizacja i działalność Gimnazjum i Liceum im. Sułkowskich w Rydzynie, „Rocznik Leszczyński”, 2 (1978) s. 93-122.

Preibisz L., Zamek i klucz rydzyński, Rydzyna 1938.

Świeboda J., Collegium Ressoviense w życiu Polaków 1658-1983, Rzeszów 1983.

Uniewska U., Gimnazjum i Liceum im. Sutkowskich w Rydzynie 1928-1939, „Amicus. Niezależna Szkoła w Polsce", 3 (2000) nr 1 (21), s. 23-30.

Wierzbicki Z.T., Wprowadzenie, w: T. Łopuszański, Tezy. Od pedagogiki narodowej do pedagogiki europejskiej, red. Z. T. Wierzbicki, Warszawa-Rydzyna 2000. 